Calving ability of a bull can be estimated as sire or as grandsire. Are studied the effects of a selection based on: 1 ) the averages for bulls as sires; 2) the averages for bulls as grandsires; 3) a weighed average of the two - for different values of the variance of maternal effects relative to the variance of direct effects and for different values of the correlation between these two kinds of effects.

It is recommended, for problem breeds, to characterize the genotypes as completely as possible, through progeny-testing and look for favourable genetic combinations regarding: I) final weight; 2) carcass composition; 3) calving ability in its direct and maternal components.

\title{
FRFAHRUNGEN MIT UND AUSSICHTEN AUF ANTAGONISTISCHE SELEKTION (AS)
}

\section{F. PIRCHNER}

\section{Lehrstuhl für Tierzucht der Technischen, Universität München,} D-8050 Freising-Weihenstephan

As und Restringierte Index Selektion (RIS) werden in zunehmendem Maße experimentell bearbeitet. Die Erfolge sind geringer als erwartet, auch wenn die verminderte genetische Variabilität $\left(\mathrm{I}-r_{\mathrm{G}}^{\mathrm{c}}\right)$ in Rechnung gestellt wird. Nichtsdestoweniger konnten in den meisten Versuchen Veränderungen in der gewünschten Richtung erzielt werden, wenn diese auch nur halb so groß wie erwartet waren. Neben Zufallsdrift und ungenauen Parameterschätzungen scheint bei AS auch die Veränderung der genetischen Korrelation bzw. ihre Asymmetrie eine größere Rolle als in einfachen Selektionsexperimenten zu spielen.

In Haustieren verhalten sich eine Reihe von Merkmalen antagonistisch. In einer Reihe von Rassen und Schlägen konnten solche auch in zufriedenstellender Weise kombiniert werden. Preisverhältnisse allerdings verhindern häufig die Inkaufnahme geringen Zuchtfortschritts des Hauptmerkmales die sich bei AS einstellen würde.

\section{ANTAGONISTIC TRAITS IN PIG BREEDING}

\section{E. STEANE}

Meat and Livestock Commission, P.O. Box 44,
Queensway House, Blechtley MK2 $2 E F / U . K$.

A review of some of the literature on antagonistic traits is presented.

In reproductive aspects there is evidence concluding that selection for decreased fatness and /or increased growth would not adversely affect reproductive traits. However, it is clear that there is an environmental/maternal effect in some populations operating against large litter size. Little evidence is available on behavioural aspects.

There is no clear evidence regarding the relationships between feed intake, feed efficiency, growth and lean but most workers agree that selection for growth and for loin eye area will be difficult due to the antagonism between them.

Meat quality aspects are not the remit of this paper but clearly selection for increased lean will, in many popuations, resuit in antagonistic responses for carcass quality.

Relationships which are less than optimal and, therefore, to an extent detrimental, are discussed.

It is concluded that whilst the antagonisms may not be consistent over breeds there is sufficient evidence to indicate the further development will probably be by the use of specialised sire and dam lines, although this policy may create problems for public schemes.

\section{SIMULTANEOUS SELECTION WITH FIXED CULLING IAEVELS} IN THE CASE OF CORRELATED TRAITS

\section{A. EBL}

\section{Institut f. Tierproduktion der Universität für Bodenkultur Wien, Austria}

The special properties and relative efficiency of simultan-selection with fixed selection limits are discussed dependent on selection intensity, correlations between traits, and the relation of the selection limits. The essential results are as follows: 
- Negative correlations of traits afford substantial lower minimum-requirements than positive correlated traits.

- The best relation of the selection limits of the individual traits is at function of the percentage of selection, of the phenotypic and genetic covariances between the traits, and of the ecotlomic weights. To find the optimal selection limits a very high calculation expense is require, if there ase more than two traits considered.

- The relative inferiority of an optimal simultan-selection in comparison with index selection ranges from 2 to $4^{\circ}$ per cent. The inferiority increases if more traits are considered, if the percentage of selection is enlarged and if the antagonism between the traits is more pronounced.

- Therefore the simultan-selection can be recommended as an alternative to index selection only, if we can select very intense and if the selection is restricted to two positive correlated traits, which can't be recorded at the same time.

\author{
CORRELATED EFFECTS OF EXTREME SELECTION ON FATTENING \\ AND CARCASS TRAITS IN PIGS \\ R. SII,ER and F. PLOCEK \\ Research Institute of Animal Production, Prag
}

Results of the progeny testing of $\mathrm{I} 8 \mathrm{I}$ Czech Large White boars in 1978 were used to analyze the effectiveness of extreme selection. Groups with extreme average daily gain (835 g) showed a less favourable backfat thickness $(2.77 \mathrm{~cm})$ and a low lean from ham $(\mathrm{I} 7.38 \mathrm{p}$. Ico). These unfavourable relations were already not so expressive in the case of eye muscle area. As a consequence of selection for low backfat thickness $(2.50 \mathrm{~cm})$ less favourable value of average daily gain $(763 \mathrm{~g})$ was found. On the basis of these results it is possible to conclude that selection for high daily gains is not suitable. Generally it is to emphasize that by extreme selection still a corresponding response can be achieved but this effect bas to be evaluated with regard to negatively correlated effects.

SELECTION FOR PROLIFICACY IN SHEEP IN RELATION TO MEAT PRODUCTION CHARACTERS

\author{
J. B. OWEN, K. BROWN and R. FLIN'T \\ Department of Agriculture, University College of Noth Wales \\ Bangor, Guyneda, U.K.
}

In diesem Beitrag werden die vorläufigen Ergebnisse einer Untersuchung über die Eigenschaften von Mutterschafen untersucht, die sich deutlich in Merkmalen der Fruchtbarkeit unterscheiden.

In dem Versuch wurden die Mutterschafe in 3 Gruppen aufgrund ihrer Fruchtbarkeitsmerkmale eingeordnet. Trotz unterschiedlicher Ablammzahlen ergeben sich wenig Unterschiede in den Nachkommengruppen, mit der Ausnahme, daß in der Gruppe mit der höchsten Fruchtbarkeit die Verluste hoch waren und gelegentlich unfruchtbare weibliche Lämmer geboren wurden.

Die Ergebnisse zeigen, daß weitreichende Unterschiede in der Fruchtbarkeit von Mutterschafen verbunden sind mit einigen wenigen Unterschieden in anderen Merkmalen. Eine bessere Lämmer-produktion ohne nachteilige Folgen kann mit der Verwendung von Mutterschafen init sehr guter Fruchtbarkeit erreicht werden.

AN'TAGONISTIC SELECTION FOR CORRELATED BODY WEIGH'T TRAITS OF MICE

$$
\begin{gathered}
\text { V. BUTLER, I., H. WILLEKE and F. PIRCHNER } \\
\text { University of Technology Munich, Weihenstephan, } \\
\text { D-8050 Freising-Weihenstephan }
\end{gathered}
$$

To verify the effects of antagonistic selection, mice were selected for high 3 - to 5 weeks body weight gain and low body weight at 8 weeks of age. The selection program involved also single trait mass selection for high 3 - to 5 weeks body weight gain and high and low 8 weeks 